\title{
O ENLACE RIO-MINAS-ESPÍRITO SANTO NA REDE GEOGRÁFICA DO TRANSPORTE RODOVIÁRIO DE CARGA
}

\author{
THE RIO-MINAS-ESPÍRITO SANTO LASHING IN THE \\ ROAD FREIGHT TRANSPORT GEOGRAPHICAL NETWORK
}

\author{
Daniel Monteiro Huertas \\ dmh@usp.br \\ Universidade de São Paulo
}

\begin{abstract}
RESUMO
Em análise estruturada a partir da teoria do espaço geográfico, este artigo pretende demonstrar as peculiaridades e dinâmicas territorias que corroboram a inserção de um conjunto nodal formado pelos polígonos fluminense (Resende-Três Rios-Petrópolis-Rio de Janeiro) e mineiro (Divinópolis-Conselheiro Lafaiete-Belo Horizonte-Ipatinga), e pelos eixos capixaba (Cachoeiro de Itapemirim-Vitória-Aracruz) e Macaé-Arraial do Cabo (RJ), como centralidades da rede geográfica do transporte rodoviário de carga, cuja configuração territorial é composta por linhas e nodais que em seu conjunto expressam a organização e estruturação desta atividade na formação socioespacial brasileira e evidenciam um processo de seletividade espacial que privilegiou certos pontos e áreas em detrimento de outros, demarcado pela concentração e atuação de seus agentes.
\end{abstract}

Palavras-chave: transporte rodoviário de carga, circulação, nodal e seletividade espacial.

\begin{abstract}
In structured analysis from the theory of geographical space, this article aims to demonstrate the peculiarities and territorial dynamics that confirmed the insertion of the nodal complex composed by fluminense (Resende-Três Rios-Petrópolis-Rio de Janeiro) and mineiro (Divinópolis-ConselheiroLafaiete-Belo Horizonte-Ipatinga) polygons, and by capixaba (Cachoeiro de Itapemirim-Vitória-Aracruz) and Macaé-Arraial do Cabo axes like centralities of road freight transport geographical network, whose territorial configuration consists of nodals and lines which together express the organization and structuring of this activity in the Brazilian social and spatial formation and show a selective spatial process that privileged certain points and areas in detriment of others, marked by concentration and action of its agents.
\end{abstract}

Keywords: road freight transport, circulation, nodal and spatial selectivity. 


\section{Introdução}

O aprofundamento e a capilaridade da globalização pelo território nacional a partir de meados dos anos 1990 impuseram mudanças profundas no cenário do comércio exterior, das forças produtivas e do padrão de consumo, elementos que, em conjunto, também impactaram o transporte rodoviário de carga, cujas variáveis são capazes de revelar o uso do território no período atual. Nessa perspectiva, a logística, como versão atual da circulação corporativa caracterizada por um conjunto de competências operacionais, materiais e normativas(CASTILLO, 2011), surge de forma arrebatadora e acarreta mudanças estruturais e conjunturais em toda a instância produtiva e no seu enlace com a circulação.

A promulgação da lei $n^{\circ} 11.442$, de 5 de janeiro de 2007, instituiu um novo quadro normativo e enquadrou o transporte rodoviário de carga (TRC) como aquele "realizado em vias públicas, no território nacional, por conta de terceiros e mediante remuneração", cuja atividade econômica "é de natureza comercial, exercida por pessoa física ou jurídica em regime de livre concorrência", segundo os artigos $1^{\circ}$ e $2^{\circ}$ da lei supracitada.

A norma, portanto, distingue o transporte rodoviário de carga da figura do carga própria (agente que não realiza o transporte com natureza comercial) e também procura discriminar e disciplinar os seus agentes (empresas de transporte rodoviário de carga/ETC e transportadores autônomos de carga/TAC, agregados e independentes) e atividades correlatas mediante coordenação e fiscalização da Agência Nacional de Transportes Terrestres (ANTT). Trata-se de um universo de 128.700 empresas transportadoras, 689.953 motoristas autônomos e 1.911 .172 veículos espalhados por todos os cantos do país, segundo dados da ANTT (15.mai.2013).

Em análise estruturada a partir da teoria do espaço geográfico, o uso do território pode ser evidenciado por um processo de seletividade espacial que privilegiou certos pontos e áreas em detrimento de outros. Como o transporte também pode ser considerado um dos fatores locacionais por conta das possibilidades que oferece para a redução de custos (THOMSON, 1976), os agentes dos circuitos espaciais de produção (SANTOS, 1988) buscam atuar em sintonia com os agentes do TRC. 
As solidariedades organizacionais geradas estimulam e facilitam a localização dos agentes em pontos privilegiados do território, geralmente nodais situados em tramos estratégicos da rede rodoviária e da rede urbana. Afinal, como já nos disse Milton Santos (2004) em sua análise do imperativo da fluidez, não basta produzir; é indispensável pôr a produção em movimento.

Levando-se em consideração que o TRC cria uma topologia própria, cuja configuração territorial é composta por linhas e nodais que em seu conjunto modelam uma rede geográfica capaz de expressar a sua organização e estruturação na formação socioespacial brasileira (HUERTAS, 2013), este artigo pretende demonstrar as peculiaridades e dinâmicas territorias que corroboram a inserção dos polígonos fluminense (Resende-Três Rios-Petrópolis-Rio de Janeiro) e mineiro (DivinópolisConselheiro Lafaiete-Belo Horizonte-Ipatinga) e dos eixos capixaba (Cachoeiro de Itapemirim-Vitória-Aracruz) e Macaé-Arraial do Cabo (RJ) como centralidades da rede em questão.

Trata-se de um conjunto nodal enlaçado pelas BRs 040 (Rio de Janeiro-Sete Lagoas), 101 (Rio de Janeiro-Vitória) e 262 (Belo Horizonte-Vitória) com predominância de nodais secundários polifuncionais, diretamente atrelados à logística de atividades industriais, e a ocorrência de um nodal secundário monofuncional ligado à logística da exploração offshore de petróleo (como será visto mais adiante). Este conjunto registra 75 matrizes de empresas transportadoras e 719 filiais espalhadas por 74 cidades, segundo a pesquisa realizada.

\section{Nodais como máxima expressão da seletividade espacial}

O ponto inicial analítico proposto, em termos de circulação, é a configuração de uma rede geográfica do transporte rodoviário de carga reveladora do uso do território. Roberto Lobato Corrêa (1997, p.306) demonstra como as redes geográficas são construções sociais "historicamente contextualizadas, constituindo-se em parte integrante do longo e cada vez mais complexo processo de organização espacial”, e locus da efetivação das interações espacias "a partir dos atributos das localizações e das possibilidades reais de se articularem entre si”. 
Organizamos o estudo da rede geográfica em questão para o território brasileiro levando em consideração funcionalidades, hierarquias e polarizações, atributos que em seu conjunto mais amplo denotam tanto a dissociação quanto a conectividade geográfica dos lugares e a seletividade espacial. Acreditamos, assim, que este caminho metodológico proporcione uma leitura bastante interessante no que diz respeito ao uso do território, evidenciando com mais força a hierarquia dos lugares gerada pela circulação diferenciada do excedente (ARROYO, 2005).

Os nodais ajudam a explicar a rede geográfica e são tidos, portanto, como a expressão máxima da seletividade espacial do transporte rodoviário de carga pela densidade de fixos e pela frequência, qualidade e intensidade dos fluxos. Do ponto de vista operacional, apenas nos nodais registra-se a possibilidade de implementar uma distribuição territorial completa das mercadorias em fluxos T1 (escala nacional-T1/A, macrorregional-T1/B e mesorregional-T1/C) e T2 (escala microrregional-T2/D, intraurbana metropolitana-T2/E eintraurbana intermediária-T2/F), cujos movimentos demarcam a escala de atuação de empresas transportadoras e motoristas autônomos (HUERTAS, 2013).

Além disso, são os principais pontos de origem e destino de todo o movimento de carga lotação (ou carga fechada, com carregamento num único ponto e entrega num único ponto) empreendido no país, embora não haja estatísticas que possam comprovar este fenômeno.

Logo de imediato é importante salientar algumas considerações gerais a respeito dos nodais. Em todos os casos ocorre uma espécie de "nexo territorial", consubstanciado pela conjugação entre a capacidade dos agentes instalados em condicionar arranjos territoriais em todas as escalas (fluxos T1 e T2), a formação do valor do frete e as amplas condições de fluidez territorial, o que significa situação locacional em trechos privilegiados da rede rodoviária nacional e acesso facilitado a portos, ferrovias, hidrovias e aeroportos. Corresponde, portanto,às interações espaciais que reforçam a interconectividade entre os agentes do transporte rodoviário de carga e destes com os agentes dos circuitos espaciais de produção.

Esta condição única no território nacional, portadora de verticalidades que criam e recriam solidariedades organizacionais, revela a estrutura e organização socioeconômica e política superior dos nodais em relação ao TRC. “...as metrópoles 
econômicas nacionais usufruem de posição estratégica na moderna rede de transporte. Isso lhes assegura relações mais fáceis com o resto do território, aumentando assim sua capacidade de competição" (SANTOS, 2008, p.309).

As características acima denotam a localização dos fixos mais estratégicos em termos de expedição, transferência e consolidação de carga e capacidade de armazenagem, além da presença de pessoal mais qualificado para o desenvolvimento das tarefas administrativas e operacionais que envolvem o TRC. Segundo estudo do Geipot citado por Silva Junior (2004), $1 / 3$ do total da frota de caminhões do país opera em percursos rodoviários (fluxos T1 e T2/D), viagens de média e longa distância com custos de transferência representativos por causa dos fixos. Soma-se a isso o fato de que nas operações de coleta e entrega (fluxos T2/E e T2/F), cujo volume também está bastante concentrado nos nodais, os custos fixos dos veículos pefazem mais de $60 \%$ do total dos custos operacionais, segundo Giúdice (2012).

Entende-se assim que os nodais concentram boa parte dos custos totais do TRC, elemento fundamental para o planejamento estratégico do circuito superior. No plano político, concentram grande parte das instituições responsáveis pela representação de suas categorias, com capacidade de debater e direcionar os assuntos normativos correlatos à atividade, com forte influência na regulamentação do setor. "Em regra geral, os atores que possuem os nós detêm o controle dos dispositivos: é nos polos que se efetua o tratamento estatístico dos objetos, garantia da qualidade da prestação global, que se organiza a cadeia de entrega com suas subcontratações hierárquicas" (SAVY, 1993, p.216; tradução livre).

De modo geral, observa-se que todas as características supracitadas são típicas de cidades com maiores níveis de especialização e diversificação econômica, em hierarquias superiores na rede urbana brasileira, cuja concentração de variáveis diretamente relacionadas ao TRC proporciona uma sinergia territorial entre os agentes e acaba reforçando o poder de polarização e centralidade das aglomerações urbanas onde se localizam - geralmente no entorno de grandes cidades, nós de circulação e pontos de convergência das vias de comunicação com interpentração de circulação geral e local (CLOZIER, 1963).

No processo de urbanização, há [...] uma tendência crescente à diferenciação e à especialização, acompanhada de uma maior

Geo UERJ. Rio de Janeiro - Ano 16, no. 25, v.2, $2^{\circ}$ semestre de 2014, pp.366-396

ISSN: 1415-7543 E-ISSN: 1981-9021

http://www.e-publicacoes.uerj.br/index.php/geouerj 
divisão interurbana do trabalho, e atrelada diretamente às possibilidades de articulação que a dinâmica da circulação promove (ARROYO, 2006, p.76).

De certa forma o nodal está vinculado a uma economia complexa, "caracterizada, e viabilizada, por uma complexa divisão territorial do trabalho", e associado à rede urbana, "cujos centros estão fortemente integrados entre si" (CORRÊA, 2006, p.306). Mas os nodais também revelam situações intermediárias, que ajudam a compreender com mais profundidade a correlação de forças entre os agentes do transporte rodoviário de carga e os níveis inferiores da rede urbana brasileira.

Esses sistemas de tessituras, de nós e de redes organizadas hierarquicamente permitem assegurar o controle sobre aquilo que ser distribuído, alocado e/ou possuído. Permitem ainda impor e manter uma ou várias ordens. Enfim, permitem realizar a integração e a coesão dos territórios. Esses sistemas constituem o invólucro no qual se originam as relações de poder (RAFFESTIN, 1993, p.151).

Além disso, se a circulação diferenciada do excedente cria uma hierarquia entre os lugares (ARROYO, 2005), os nodais podem ser analisados, também, pelas grandes possibilidades que oferecem para reter boa parte deste excedente, porque "sem a circulação de bens não há circulação do excedente" (SANTOS, 2003, p.144).

São nos nodais que se materializam no território as maiores possibilidades daquelas metamorfoses M-D e D-M explicadas por Marx, fenômeno que intensifica o que ele chamou de "processo adicional da produção da indústria de transportes", visível na densidade do trinômio proposto. Além disso, são nos nodais que a aplicação da lei geral da produção de mercadorias, que também "se aplica à indústria de transportes como a qualquer outra" (MARX, 2011, p.167), adquire a sua condição plena, pois a concentração de agentes da circulação nesses nexos territoriais favorece a diminuição dos custos de transporte.

Ademais, valendo-se ainda da teoria marxista, são nos nodais que residem as maiores possibilidades de balanceamento entre o tempo de compra e de venda - cuja soma define o tempo de circulação do capital, uma das frações do ciclo de circulação do capital como um todo -, pois "o afastamento do mercado prolonga o tempo em que o capital fica prisioneiro da forma de capital-mercadoria, retarda diretamente o retorno do 
dinheiro, por conseguinte a transformação do capital-dinheiro em capital-produtivo" (MARX, 2011, p.290).

O autor explica que a repartição do retorno do dinheiro "por maior número de períodos sucessivos encurta o tempo global de circulação e, por conseguinte, a rotação" (MARX, 2011, p.287), condição possível, para o caso específico da formação socioespacial brasileira, pelo entrelaçamento territorial proporcionado pelos nodais, que amarram os principais mercados produtores e consumidores de um país com dimensões continentais e desequilíbrios regionais.

Nos nodais observa-se um melhor desenvolvimento dos meios de transporte, fato que "aumenta a velocidade do movimento no espaço e assim reduz-se no tempo a distância geográfica” (MARX, 2011, p.286). Esta redução absoluta do tempo de viagem das mercadorias, embora permaneça a diferença relativa, só é possível pela maior frequência com que funcionam os agentes da circulação nos nodais, além da amplitude de suas escalas de atuação no território nacional.

$\mathrm{Na}$ divisão territorial do trabalho do período atual, os nodais do transporte rodoviário de carga, locus de alta produtividade espacial ou subsistemas logísticos que facilitam a fluidez e hierarquizam o território pelos seus requisitos técnicoorganizacionais (SANTOS, 2004), proporcionam um movimento convergente de articulação do todo nacional, embora o espaço se torne "mais articulado às relações funcionais, e mais desarticulado quanto ao comando local das ações que nele se exercem" (SANTOS, 2005, p.49). A análise geográfica, portanto, parte do princípio de que o espaço também se impõe por meio das condições que oferece para a circulação.

\section{Atributos geográficos dos nodais que reforçam centralidades}

Como visto anteriormente, o nodal denota a capacidade de produzir, coletar, armazenar e distribuir das áreas sob sua influência e se torna uma arena territorial privilegiada aos agentes por causa da cadeia de subcontratações, que aí encontra as maiores probabilidades de realização pelo encontro entre oferta e demanda por serviço de transporte. No embate entre arena e área, proposto por Milton Santos (2005), os nodais são arenas que proporcionam o alargamento de atuação territorial dos agentes 
dos circuitos inferior e superior, ou seja, de suas áreas de operação - que podem ser rotas programadas ou de acordo com a conveniência do cliente.

Como escolher, então, as variáveis, ou melhor, os atributos geográficos constituintes dos nodais do TRC? Ao longo da pesquisa, fruto da observação empírica de nosso objeto de estudo, foi concebido um agrupamento tipológico sob o prisma da correlação do trinômio máquina (veículo) $\leftrightarrow$ agentes da circulação $\leftrightarrow$ fixos (rodovias e suportes). Os elementos escolhidos e discriminados abaixo, com elevado grau de concentração nos nodais, tem como objetivo comprovar territorialmente a densidade e escala de objetos ligados direta ou indiretamente ao TRC, o que de certa forma ajuda a corroborar a hierarquia dos lugares no que diz respeito à circulação:

(1) Veículos: revendas de todas as marcas de caminhão comercializadas no Brasil (Agrale, Ford, Hyundai, International, Iveco, MAN, Mercedes-Benz, Scania, Volvo e Sinotruk); rede de distribuidores dos cinco mais expressivos fabricantes de implementos rodoviários (Randon, Librelato, Facchini, Noma e Guerra) e oficinas Bosch Diesel Center, tidas como especializadas em serviços mecânicos e eletrônicos com soluções de reparo dos sistemas diesel (Common Rail e outros) em equipamentos de última geração.

Também é importante destacar que ao longo dos nodais, mais especificamente nas principais vias e trevos de acesso às cidades que os compõem, registra-se uma miríade de oficinas que prestam inúmeros serviços de manutenção e reparo de caminhões e implementos rodoviários, borracharias e revendas de veículos usados. São estabelecimentos de todos os portes - precários e modernos; pequenos, médios e grandes -, mas constantemente presentes na paisagem. Alguns funcionam 24 horas, sempre aptos a prestar assistência ao caminhoneiro.

Dentre os serviços mais ofertados estão chapeação (funilaria), pintura, lavagem, autoelétrico, recapagem de pneu, retífica e usinagem de motores, substituição de bomba injetora de óleo diesel, troca de lona de freio e reparo de diferencial e caixa de câmbio. Os postos de combustível, além do abastecimento, funcionam como ponto de apoio e oferecem pequenos serviços emergenciais de mecânica, lavagem, calibragem de pneus, sanitários, restaurante e estacionamento para pernoite. Alguns ainda possuem serviços como barbearia, salão de jogos, sala de TV, comércio de artigos para caminhão (adornos, enfeites, lâmpadas, para-choques, adesivos etc) e agenciamento de carga. 
(2) Agentes: Empresas transportadoras de carga (ETC) e transportadores autônomos de carga (TAC) cadastrados no Registro Nacional de Transportadores Rodoviários de Carga (RNTRC) da ANTT; motoristas com vínculo empregatício segundo a Relação Anual de Relações Sociais do Ministério do Trabalho e Emprego (Rais/MTE); unidades do Sistema Sest/Senat, mantido pela contribuição sindical de todos os agentes e gerenciado pela Confederação Nacional dos Transportes (CNT), e organização sindical do empresariado e de autônomos.

(3) Fixos logísticos: cada tipo de fixo surge com características próprias (técnicas e organizacionais) que corresponde a uma tipologia de fluxos (SANTOS, 1988). Desse modo ofuncionamento do território não pode ser compreendido sem a alocação dos fixos que captam o movimento de boa parte dos fluxos rodoviários que perpassam o território nacional, seja para o mercado interno ou externo. Além disso, são grandes indicadores das forças de dispersão e concentração geradas pelo binômio informaçãoconsumo (SANTOS, 2008), ponto central para a compreensão dos circuitos espacias e círculos de cooperação do TRC.

Em sua proposição de uma tipologia de nós geográficos, Vanderlei Braga (2013, p.45) coloca como objetivo "discriminar e classificar os sistemas técnicos que envolvem o movimento de mercadorias, sem esquecer as relações políticas, econômicas e sociais que articulam e hierarquizam estes pontos, planejados para serem estrategicamente localizados no território". Para o autor, os nós geográficos podem ser classificados “de acordo com sua função e complexidade, decorrentes de distintas combinações entre objetos técnicos e normas que incorporam" e estão subdivididos em nós de comunicação e de circulação. Estes, por sua vez, incorporam nós de transporte de passageiros, de transporte de cargas simples e logísticos.

Levando-se em consideração os dois últimos, que nos interessam mais de perto, observamos que armazéns simples, centrais (ou centros) de distribuição, plataformas e condomínios logísticos, terminais intermodais (aeroportuários, aquaviários e ferroviários) e centros logísticos e industriais aduaneiros (Clias) estão entre os fixos adotados pelo autor para corroborar o seu ponto de vista. Em nossa análise, focada no TRC, acrescentaremos os pontos de combustível com agenciamento de carga, os 
recintos alfandegados pela Receita Federal (portos secos e pontos de fronteira), as unidades superiores de triagem dos Correios e os entrepostos da Zona Franca de Manaus (EZFM).

(4) Rede rodoviária: em conjunto com os nodais, as linhas rodoviárias de circulação revelam a rede geográfica do TRC. Como aponta Brandão (2009, p.78-9), "tornar os espaços conexos não é uma tarefa que ocorre com naturalidade", e a ação das forças de integração "geralmente constitui um longo, contraditório, heterogêneo e conflituoso processo em que os espaços regionais circunscritos e capsulares vão sendo enredados a partir daquele(s) espaço(s) em que prevalecem formas superiores de acumulação e reprodução econômica".

É fato que a expansão rodoviária no país é iniciada nos anos 1930 com Getúlio Vargas e incrementada sucessivamente por Juscelino Kubitschek e pela ditadura militar ao longo da segunda metade do século XX; emoutras palavras, o enraizamento das linhas rodoviárias só pode ser compreendido mediante análise do processo histórico da formação socioespacial brasileira, que deve mostrar porque uma via foi aberta - e mais, porque foi aberta para ligar os pontos A e B, e não A e C. Geralmente, há um imbricamento de motivações geoeconômicas e geopolíticas; muitas vezes, uma prevalece sobre a outra.

Mas como pensar as linhas de circulação para a proposta deste trabalho e para o período atual? Primeiramente concordamos com a assertiva de Milton Santos (2008, p.313) sobre a rede de transportes nos países subdesenvolvidos, "nem homogênea nem contínua, mas dendrítica", cujas principais rodovias "ligam os grandes centros de produção aos principais centros de consumo". Optamos por um esquema simples, composto por três conjuntos rodoviários:

- Eixos centrais (estruturantes): são as ligações de alta densidade de tráfego e de grande importância geoestratégica, uma malha de linhas de circulação que conecta os nodais superiores do TRC majoritariamente por rodovias federais (BRs). Em termos econômicos confundem-se com as linhas de desejo que servem as principais economias de escala do país. 
- Eixos complementares: são ligações de média densidade de tráfego e de caráter mais intrarregionale/ou intraestadual do que inter-regional e/ou interestadual. Compõem as rodovias que atendem os eixos centrais tanto no seio dos nodais quanto na ligação entre linhas de nível superior. Neste caso, aparece um conjunto bastante significante de vias estaduais, sobretudo na Região Concentrada.

- Eixos em configuração na Amazônia: incluída no Programa de Aceleração do Crescimento (PAC), a pavimentação em andamento dos trechos Guarantã do Norte/MT-Santarém/PA da Cuiabá-Santarém (BR-163), Altamira-Marabá da Transamazônica (BR-230/PA) e Ribeirão Cascalheira/MT-divisa MT/PA da BR-158 a curto e médio prazos modificará a configuração territorial de extensas áreas entre o sul do Pará e o médio-norte do Mato Grosso, com iminentes impactos socioambientais.

\section{Recortes espaciais e topologia dos nodais}

Acreditamos que a busca por uma rede geográfica promovida e desenhada pelo TRC como resultado da divisão territorial do trabalho encontre sentido exatamente nesta questão, a definição de espaços de fluxos reguladores - os nodais em suas manifestações topológicas - interligados por linhas de circulação que abarcam boa parte do território nacional. Admitimos, entretanto, que esta escolha pode incorrer em erros comuns a qualquer tipo de recorte espacial estabelecido a partir de quaisquer variáveis. Não se trata de uma camisa-de-força, mas de uma sugestão para um melhor entendimento do papel do TRC na organização e estruturação da formação socioespacial brasileira.

Os nodais não deixam de ser aglomerações e a compreensão da divisão territorial do trabalho inclui, necessariamente, a análise funcional e hierárquica do TRC - evidenciando, assim, o uso do território. Milton Santos (2004, p.284; grifo nosso) nos explica que, nas atuais condições, "os arranjos espaciais não se dão apenas através de figuras formadas de pontos contínuos e contíguos". E continua: "Hoje, ao lado dessas manchas, ou por sobre essas manchas, há, também, constelações de pontos descontínuos, mas interligados, que definem um espaço de fluxos reguladores." 
O recorte espacial dos nodais, como proposta metodológica, considera a relação entre quantidade e contiguidade de matrizes e seus fixos correlatos (filiais, centros de operação, pontos de apoio, centros de distribuição, agências, centros de envio e franquias) de uma relação de 800 empresas transportadoras levantadas em pesquisa de elaboração própria como o indicador que esclarece os arranjos territoriais do TRC ao longo da formação socioespacial brasileira, relacionando-o com a rede rodoviária nacional e a rede urbana (HUERTAS, 2013). A pesquisa apontou 7.401 fixos em 1.087 cidades de todas as Unidades da Federação, sendo que, respectivamente, 6.936 $(93,71 \%)$ e 695 (63,93\%) estão situados nos nodais, classificados em quatro níveis:

(i) Primário: "polígono paulista", força polarizadora única no território nacional que acolhe 304 matrizes (38\% do total), com 1.618 fixos (21,8\%) alocados em 144 cidades $(13,2 \%)$, e responsável pela determinação das rotas, prazos de tempo de trânsito de carga e valor do frete de boa parte do país;

(ii) Secundários polifuncionais: aqueles em que os circuitos espaciais de produção industrial são o suporte das atividades geradoras de carga, tornando o seu tecido econômico mais diversificado e complexo;

(iii) Secundários monofuncionais: aqueles cuja tipologia pode estar relacionada à especialização produtiva (circuitos espaciais de produção petrolífera e agropecuária), à situação geográfica (acesso fronteiriço ao Mercosul) ou à logística do comércio atacadista e distribuidor e da produção salineira;

(iv) Terciários (relês regionais): centros responsáveis por fluxos T2/D (rotas microrregionais) e T2/F (cidades intermediárias).

A configuração de um nodal em cidades que dispõem de pelo menos três fixos e/ou de uma matriz é uma condição restrita ao nodal terciário, o mais baixo da classificação proposta. Os dois níveis superiores, ou nodais primários e secundários, somente ocorrem em cidades com seis ou mais fixos e pelo menos uma matriz, sendo que a sua composição completa, no caso de eixos e polígonos, deve incluir também 
todas as cidades adjacentes aos seus eixos rodoviários estruturantes que contam com pelo menos um fixo.

De certa forma, esta proposta metodológica constrói-se a partir do circuito superior do transporte rodoviário de carga (grandes e médias transportadoras), embora os circuitos superior marginal e inferior (pequenas transportadoras e motoristas autônomos) estejam diretamente atrelados e subordinados, espacialmente falando, aos desígnios técnico-operacionais e informacionais dos agentes hegemônicos.

A pesquisa desenvolvida ainda indica que as empresas de transporte rodoviário de carga pensam o Brasil no sentido longitudinal (norte-sul), até uma faixa de cerca de 200 km do litoral no Nordeste e de $600 \mathrm{~km}$ na Região Concentrada - obviamente onde se concentram os seus principais centros produtores e consumidores. Fora dessa zona, apenas alguns nodais e relês aparecem como centralidades associadas ao TRC no Brasil contemporâneo, fato que de certa forma demonstra a leitura territorial de "estilo christalliana" exercida pelo mercado.

Isso também significa que, de forma geral, o atendimento ao extenso interior do país é feito de modo mais otimizado e lento, pois o crescimento das distâncias é proporcional à diminuição dos mercados (ou seja, menos carga para transportar), situação que requer do transportador ajustes, adaptações e parcerias. A pesquisa também demonstra que a distribuição espacial de nodais ao longo do território nacional pode ser um dos indicadores das crônicas e históricas desigualdades regionais, principal característica da formação socioespacial brasileira.

\section{O enlace rodoviário Rio-Minas-Espírito Santo}

O polígono fluminense (DIAGRAMA 1) é composto pelo eixo da Dutra (BR116), Baixada Fluminense e subida da serra por Petrópolis (BR-040) e Teresópolis (BR116, o início da chamada Rio-Bahia). Em Duque de Caxias, residem três das mais tradicionais ETCs do Brasil: a Carvalhão, que opera carga especial desde 1960, e Atrevida e A. Cupello, no transporte de combustível desde 1958 e 1961, respectivamente. Na cidade situa-se um dos maiores terminais de carregamento de combustível do país (os demais ficam em Campos dos Goytacazes e Volta Redonda), e 
na BR-040 está o terminal de cargas, com várias ETCs instaladas em galpões adjacentes. As unidades do Sest/Senat ficam em São Gonçalo e na capital (2).

Em Mesquita, a São Geraldo (TSG), de 1940, trabalha com carga geral, de trânsito aduaneiro, especial, siderúrgica e contêiner. No Rio de Janeiro destacam-se Superpesa e HM, de carga especial; Agaé, que transporta asfalto e óleo combustível por todo o Sul, Sudeste e Nordeste; Tranziran, que coleta e entrega contêineres nos portos de Vitória, Rio, Sepetiba e Santos, além de carga especial; e Trelsa, de 1957, com transporte de combustível e químicos entre Bahia, Amazonas e São Paulo.

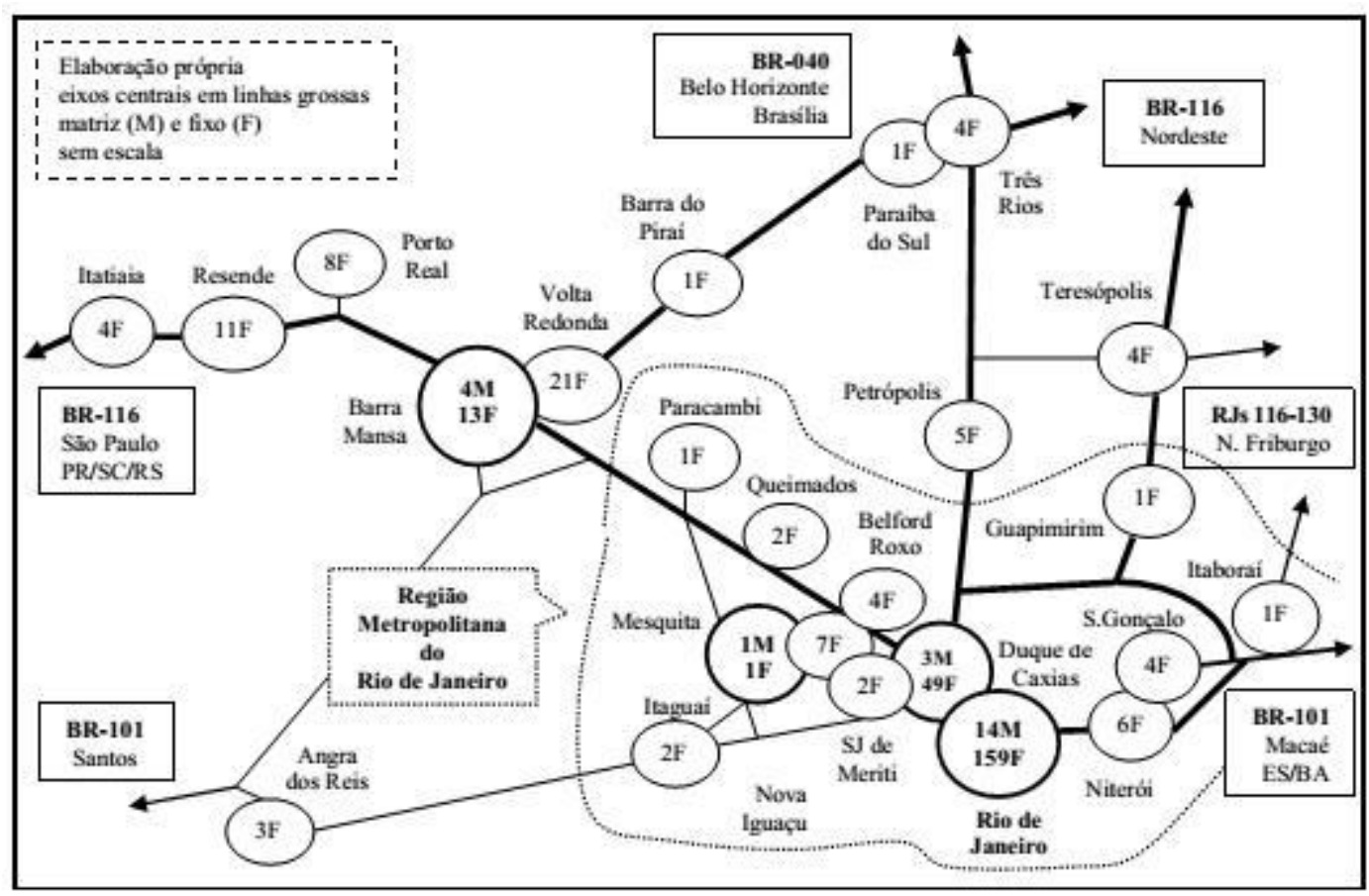

DIAGRAMA 1. Configuração territorial do polígono fluminense

A Expresso Boas Novas opera fluxos T1/B com São Paulo e Espírito Santo; a Quick realiza fluxos T1 para Paraná, Santa Catarina, Sudeste, Goiás, Bahia, Pernambuco, Ceará, Pará e Amazonas; e a Transmaliar, para São Paulo e Pernambuco. A Eureka, de 1966, possui 11 filiais em Minas, duas em São Paulo e três no Rio e transporta carga geral e confecções em cabideiro. A Transmaré trabalha com mudanças, mesmo segmento da Fink, de 1924. Esta tradicional empresa, que também opera em feiras e eventos, tem em seu currículo a contratação para participar da coordenação logística da mudança da Capital Federal entre 1954 e 1967. 
A Região Metropolitana do Rio de Janeiro (RMRJ) é um grande destino de fluxos T1, sobretudo de São Paulo (T1/B), com baixíssimas taxas de frete-retorno, conforme explicou Reinaldo da Matta Machado (informação verbal) ${ }^{1}$, diretor financeiro da Federação do Transporte de Cargas do Estado do Rio de Janeiro (Fetranscarga). A distribuição nas cidades da Baixada Fluminense (fluxos T2/E) é um indicativo da divisão territorial do trabalho. De modo geral, a lógica operante das ETCs tem um ponto específico na entrada dos principais bairros e favelas, onde se concentra a entrega para boa parte do comércio varejista.

Carga de pequenos volumes "sobem o morro" com a "subcontratação" de agentes locais autorizados pelos chefes do tráfico e/ou pelos líderes da comunidade, que então coletam as mercadorias para distribuir aos clientes (pessoa física). É a chamada "logística do morro", disse Machado, da Fetranscarga. "O mais apropriado é o caminhão descarregar em locais estratégicos nas adjacências dos bairros, em praças que dão acesso aos morros; e para subir é no braço, moto ou kombi”, disse, citando como exemplo a Praça Nossa Senhora da Penha, na Zona Norte.

O fracionamento e a descontinuidade das atividades do circuito inferior criam uma multiplicidade de serviços de contato e de articulação, assim como toda uma cadeia de outras atividades. [...] $\mathrm{O}$ abastecimento quotidiano da cidade é motivo para um grande movimento de rua e nela aparecem todos os pequenos ofícios ligados às pessoas que passam e às necessidades de um transporte fragmentado e, portanto, de pequenos volumes (SANTOS, 2008, p.253).

A capixaba Maria Ângela, moradora do Morro do Alemão desde 1990, retratou bem esta questão de forte impacto territorial ao descrever como foi a entrega de uma de suas últimas aquisições, um fogão de seis bocas, deixado na associação de moradores na metade do morro, já que o caminhão da loja não tinha condições de vencer a ladeira. "Sai mais caro que pagar frete [...], ninguém aceita subir de caminhão até o alto", disse, comentando que a alternativa encontrada foi o pagamento de $\mathrm{R} \$ 40$ para quatro vizinhos levarem o equipamento no braço ${ }^{1}$.

$\mathrm{Na}$ faixa litorânea do entorno metropolitano destaque para os investimentos da indústria naval, com 124 obras em andamento em 20 estaleiros operantes que totalizam $32,31 \%$ do setor (atrás apenas de Suape), ou 2,21 TPBs, atividade geradora de carga 
para o TRC. O porto de Sepetiba, em Itaguaí, cujo acesso se dá pelas BRs 465 e 101, tem registrado movimento crescente no transporte de contêineres. O chamado Arco Rodoviário (BR-493), obra do PAC, está sendo construído para melhorar o acesso a Itaguaí, além de criar uma alternativa de tráfego à Avenida Brasil e ponte Rio-Niterói para atravessar a Baía de Guanabara. O porto do Rio de Janeiro também se destaca pela movimentação de contêineres, com grande fluxo de carretas para entrega e coleta. Os portos secos do Estado estão em Mesquita e Resende, e o Clia, na capital.

O eixo fluminense da Via Dutra é tido como o principal do Estado por causa da aglomeração industrial comandada pelas plantas automobilísticas instaladas em Porto Real (Peugeot-Citroën) e Resende (caminhões MAN; a da Nissan está em construção) e pela Companhia Siderúrgica Nacional (CSN), em Volta Redonda, gerando e recebendo carga de vários destinos. Como exemplo, a Estapostes, de Guarulhos, mantém filiais na cidade e na vizinha Barra Mansa para operações exclusivas de carga siderúrgica.

O fluxo da "Cidade do Aço" com a RMRJ está entre os principais intraestaduais, ao lado do fluxo Rio-Campos. Pela RJ-155 são 98 km até o Porto de Angra dos Reis, que opera carga siderúrgica da CSN para longo curso e cabotagem. As unidades do Sest/Senat ficam em Barra Mansa (2), Resende e Três Rios.

Em Barra Mansa despontam quatro ETCs. A Toniato opera carga geral e insumo agrícola entre o Rio Grande do Sul e Minas Gerais, e das suas 15 filiais nove estão em São Paulo. A Nova União realiza fluxos T1/A de carga geral com Santa Catarina e São Paulo e a Expresso Andressa, com o Sul, Sudeste e Goiás. A Transporte Excelsior, de 1960, trabalha com carga siderúrgica em fluxos T1 para Bahia, Sudeste, Paraná e Santa Catarina.

Em Resende funciona o já citado Entreposto da Zona Franca de Manaus (EZFM), concedido por licitação para a estadunidense McLane, cuja subsidiária brasileira foi adquirida em julho de 2013 pela francesa FM Logistic. O gerente da empresa, Luis Henrique Viana, explicou que 26 clientes operam no regime de postergação tributária, e que o fluxo T1/A Manaus-Resende é 60\% rodoviário (10 a 12 dias de viagem) e $40 \%$ por cabotagem (95\% do desembarque em Sepetiba e $5 \%$ em Santos, entre 14 e 16 dias de viagem), mas esses números podem variar (informação

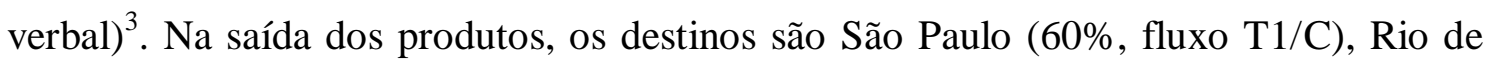
Janeiro (15\%, fluxo T1/C) e demais partes do país (25\%). 
O negócio da McLane é a gestão logística do cliente, que envolve o fornecimento de informação e armazenagem, sem realizar o transporte de fato. É uma espécie de “divisão de responsabilidades", como declarou Viana, na qual a empresa elabora o desenho logístico para o cliente e lhe oferece um leque de opções de transportadores, sem intermediar o preço do frete - que é acertado diretamente entre embarcador e destinatário da carga. O contrato de armazenagem geralmente é mensal e pode ser feito de três formas: vertical por cubagem $\left(\mathrm{m}^{3}\right)$, posição de pallet e posição no solo $\left(\mathrm{m}^{2}\right)$.

Da Via Dutra, no acesso para Volta Redonda, nasce a BR-393, que corta o antigo Vale do Café e se encontra com a BR-040 em Três Rios (RJ), já na divisa com Minas Gerais. Deste ponto são mais $68 \mathrm{~km}$ a leste até Além Paraíba (MG), onde se entronca com a BR-116, que segue para a Zona da Mata Mineira e Bahia. Ao norte, de Três Rios até Belo Horizonte pela BR-040 são 309 km em pista totalmente duplicada.

A Região Metropolitana de Belo Horizonte (RMBH) é o epicentro do polígono mineiro, que engloba ainda a Região Metropolitana do Vale do Aço (lei complementar $\mathrm{n}^{\mathrm{o}}$ 51/06) e os dois colares metropolitanos ${ }^{4}$ adjacentes (DIAGRAMA 2). Além disso, prolonga-se a leste até Itabira (BR-120), a oeste até Nova Serrana (BR-262) e Divinópolis (MG-050) e ao sul até Conselheiro Lafaiete (BR-040) e Mariana (BR-356). Em Betim localizam-se o terminal de carregamento de combustível e um Clia, e as unidades do Sest/Senat ficam em Belo Horizonte (2), Contagem, Sete Lagoas, Divinópolis, João Monlevade e Santana do Paraíso.

A principal característica no polígono mineiro é o transporte de carga siderúrgica, reconhecida pela concentração de ETCs especializadas neste circuito espacial de produção. Além disso, os dois principais fluxos intraestaduais são RMBHVale do Aço e RMBH-Sete Lagoas, com intensos e constantes carregamentos de ferrogusa e carvão vegetal. Segundo Renato Voltaire, diretor-técnico da Associação Nacional dos Usuários do Transporte de Carga (Anut) ${ }^{5}$, mesmo com amplo uso do modal ferroviário o rodoviário é responsável pela distribuição de $65 \%$ do transporte siderúrgico, ou cerca de 70 milhões de toneladas.

"Ipatinga abastece todo o Brasil", comentou Jackson Martins Cruz (informação verbal) ${ }^{6}$, presidente da Transportes Martins, dando a dimensão territorial exata das operações com carga siderúrgica, que inclui uma vasta gama de insumos (escória, concentrado de cobre, cal virgem, calcário, pasta eletroídica, carvão coque, mineral e 
vegetal, minérios granulados em geral, ferro-gusa e ferro-ligas) e produtos finais (aço pelotizado, bobinas, fardos, tubos e rolos de aço, vergalhão e produtos metálicos).

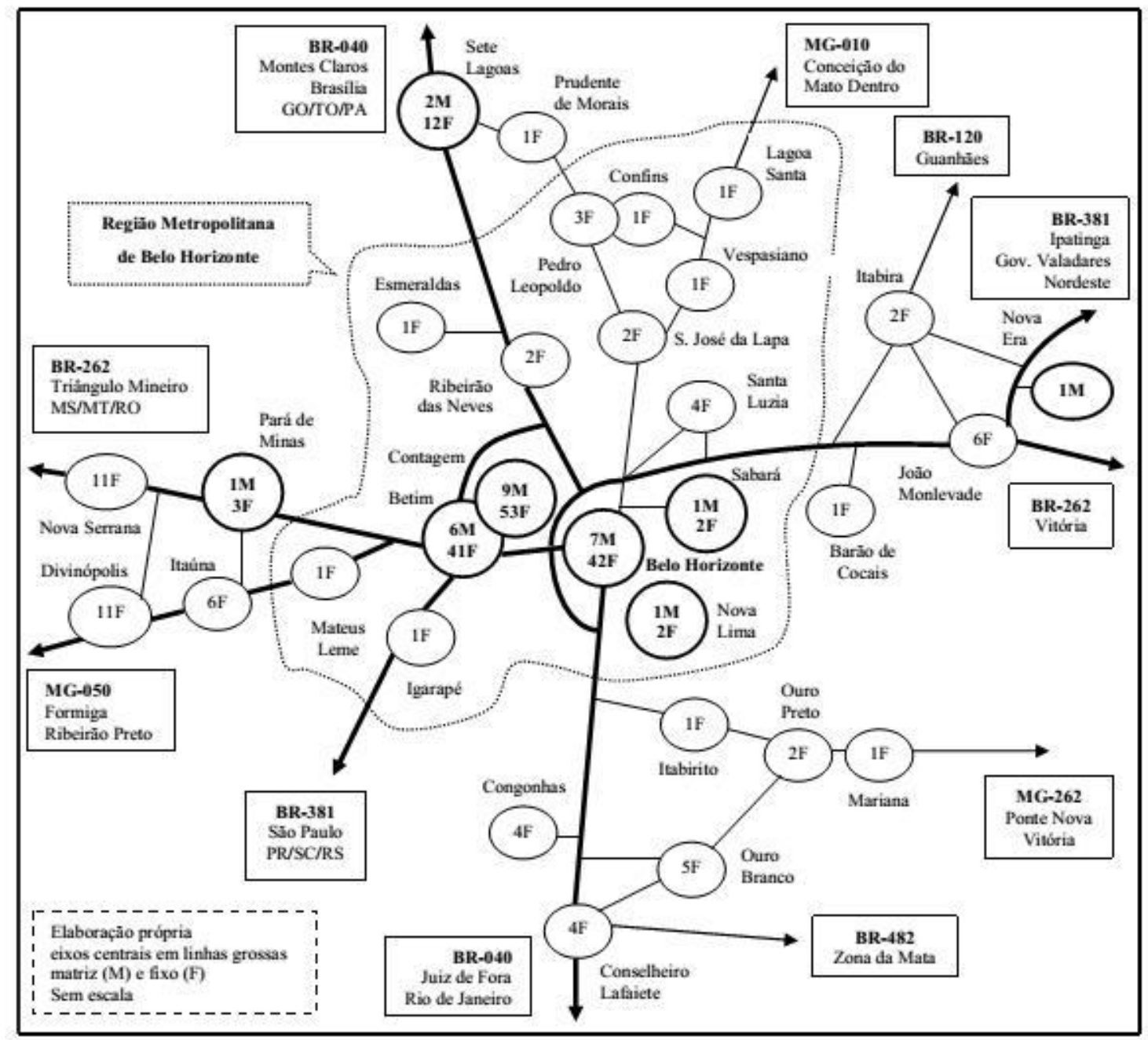

DIAGRAMA 2. Configuração territorial do polígono mineiro

Em Contagem, destacam-se a Tora, que conta com 46 filiais em todas as regiões do país; e o Expresso Lamounier, que opera fluxos T1/B com São Paulo e T1/C em Minas. A Usifast Logística possui intermodalidade rodoferroviária para siderúrgicos e insumos industriais. Na capital, a D'Granel opera fluxos T1/A e T1/B com os vizinhos do Sudeste, Goiás, Bahia e Pará, além de fluxos T1/C com 13 filiais em Minas. A Martins, uma das mais antigas do segmento (1953), trabalha com fluxos T1/B apenas na Região Sudeste. Lemarge, de Sabará; TNE, de Nova Era (entre João Monlevade e Ipatinga); e Rodeiro, de Sete Lagoas (seus clientes são Arcelor, CSN, Votorantim, 
Minas Ligas e Minas Zinco), completam o quadro das grandes ETCs mineiras do ramo siderúrgico.

Interessante notar o impacto territorial do transporte de carga siderúrgica, pois ETCs de outras partes do país que operam no segmento mantêm fixos de peso em Minas Gerais, denotando a existência de fluxos T1 próprios do circuito superior.Longos fluxos T1/A ocorrem na paraense Transgobal, com filiais em Contagem e Parauapebas (PA); e na mineira Transpes, de Betim, com filial na mesma cidade do Complexo de Carajás. A Della Volpe, de São Paulo, conta com filiais em Timóteo, Divinópolis, Belo Horizonte e Contagem; a TKE, de Araranguá (SC), em Juiz de Fora; a Gold Star, de Viana (ES), em Contagem; e a ANR, de São Paulo, em Contagem, Ipatinga, Betim, Timóteo e Santa Luzia.A empresa paulista vem desde 2009 investindo na renovação da frota, troca de equipamentos de rastreamento para agregados e transformação de carretas lisas em carretas bobineiras.

Cabe ressaltar que o alto índice de acidentes envolvendo carga siderúrgica rodoviária induziu a publicação de novas normas pelo Conselho Nacional de Trânsito (Contran), cuja resolução $n^{\circ}$ 293/08 alterou os requisitos de segurança para caminhões que operam neste segmento. Entre as medidas estão a limpeza e vedação de caçambas que movimentam minério para evitar a queda de grãos na pista; o uso obrigatório de proteções adicionais para tubos e novas exigências para o transporte de bobinas, amarradas com cintas ou cabos de aço, ganchos e catracas com resistência comprovada à ruptura por tração de, no mínimo, o dobro do peso das peças.

Documento elaborado pelo Contran constatou que a quase totalidade das empresas transportava materiais sem a devida segurança, não observando a fixação das bobinas ou fardos de chapas à carroçaria ou chassi do veículo, colocando em risco a operação, já que em curvas, lombadas ou freadas bruscas a carga tende a ser projetada na via pública.

O fluxo de produção siderúrgica explica a forte demanda rodoviária em suas duas pontas. Um dos principais insumos para a produção de ferro-gusa (que por sua vez é insumo para a aciaria) é o calcário, que juntamente com granulados de ferro e coque forma o sinter, que será levado para aquecimento nos alto-fornos.

O abastecimento de minério de ferro para os grandes conglomerados siderúrgicos (Usiminas em Ipatinga/MG e Cubatão; ArcelorMittal em João 
Monlevade/MG; Gerdau Açominas em Ouro Branco/MG, Divinópolis/MG e Barão de Cocais/MG; Aperam em Timóteo/MG; Vallourec\& Mannesmann/VMB em Belo Horizonte; Vallourec\& Sumitomo/VSB em Jeceaba/MG; CSN em Volta Redonda; Votorantim em Barra Mansa; Cia. Siderúrgica do Atlântico/CSA, no Rio de Janeiro; e ArcelorMittal Tubarão em Vitória) ocorre basicamente pelo modal dutoviário e/ou ferroviário - um trem com 77 vagões substitui aproximadamente 216 carretas $^{7}$-, mas ao longo de todo o polígono mineiro está concentrado o maior polo guseiro do mundo, com 63 indústrias metalúrgicas e 105 alto-fornos, abastecidas majoritariamente pelo circuito inferior em fluxos T2/E de baixo valor agregado e fretes igualmente baixos, com presença expressiva de autônomos agregados.

“O transportador rodoviário atende à rotatividade na relação entre redução de estoques e prazo menor de ressuprimento, a fretes baixíssimos”, explicou Luciano Medrado, gestor de Negócios e Relacionamentos da Federação das Empresas de Transportes de Carga do Estado de Minas Gerais (Fetcemg), afirmando que as plantas da antiga Cosipa (hoje Usiminas), CSN e CSA se abastecem em Minas, cuja deterioração das estradas só não é maior "por causa do aumento da vida útil do equipamento e das balanças" (informação verbal) ${ }^{8}$. E concluiu, observando que na última década tem se verificado uma tendência à especialização logística no insumo siderúrgico. "Minas faz negócio com todo o país, cuja vantagem é a fidelização e garantia, e não o valor do frete."

Do total de empresas do polo guseiro, 29 estão a oeste (nove em Divinópolis), 27 a noroeste (22 em Sete Lagoas) e sete na zona central (duas em Betim), cuja produção em 2011, segundo o Sindicato da Indústria do Ferro no Estado de Minas Gerais (Sindifer) foi de 2,5 milhões/ton para o mercado interno $(60 \%$ do total doméstico) e 3,2 milhões/ton para exportação. O ferro-gusa é insumo para ferro fundido (gusa para fundição) e aço (gusa para aciaria), servindo a indústria de transporte ferroviário, bens de capital e automobilística e as siderúrgicas.

$\mathrm{O}$ processo produtivo de ferro-gusa e aço depende do uso em escala de cal e calcário, que durante o refino do minério de ferro criam um isolamento químico entre o metal líquido e o oxigênio, evitando assim a sua oxidação. O resíduo é chamado de escória, que após ser resfriado, britado, classificado e separado serve de matéria-prima para a produção de cimento (é misturado ao carbonato de cálcio e sílica para formar um 
pó fino chamado de cru), além de base para a construção e manutenção de estradas, aterros e lastro para vias ferroviárias. Como Minas Gerais também é o maior produtor nacional de cimento, verifica-se uma sinergia territorial com os circuitos espaciais produtivos minero-siderúrgicos, na qual desempenha papel fundamental o TRC.

Entre o polo guseiro, no centro do Estado, e as principais jazidas de calcário e polos cimenteiros, no Centro-Oeste Mineiro e RMBH, existe um fluxo intenso e contínuo de veículos levando calcário e retornando com escória, motivo que coloca cidades como Itaú de Minas, Arcos, Ijaci, Santana do Paraíso, Barroso, Pedro Leopoldo, Matozinhos e Santa Luzia no mapa do TRC mineiro. No Vale do Aço há também fluxo intenso de carretas bitrem para coleta e entrega de toras de eucalipto na fábrica da Cenibra, em Belo Oriente, cuja produção de celulose segue para exportação no Portocel, no litoral capixaba, em um ramal ferroviário que contorna o curso do Rio Doce.

Quanto à carga geral, o polígono mineiro também registra a ocorrência de ETCs que operam diversos fluxos pelo país. Jamef, de 1963, e Patrus, de 1973, estão entre as maiores e mais tradicionais, ambas sediadas em Contagem. A primeira possui 22 filiais nas regiões Sul e Sudeste (sete em São Paulo), Santa Catarina, Goiás, Distrito Federal, Bahia, Pernambuco e Amazonas. A segunda conta com uma ampla rede de 59 filiais, ligando Sul, Sudeste e a Bahia, mas anuncia a "melhor e mais completa cobertura de Minas" com 22 filiais para atender os cerca de 800 municípios do Estado. Na mesma cidade a Transrefer opera fluxos T1 entre São Paulo, Rio e Goiás; a Meridional atua no Sul e Sudeste; e a Direcional no Sudeste, Goiás e Pará.

Na capital, a Minas Goiás, de 1948, opera entre Distrito Federal, Goiás, São Paulo e Rio; e a Gontijo, por intermédio de sua longa rede de agências do transporte de passageiros, coleta e entrega encomendas no Nordeste, Centro-Oeste e Sudeste. TWM e Transpedrosa, de Betim (esta é de 1962), e Niquini, de Nova Lima, transportam combustível em fluxos T1/A e T1/B. A Sada, de Betim, é uma das maiores do país no transporte de veículos por causa das operações com a Fiat, e conta com filiais no Amazonas, Goiás, Rio e São Paulo.

A Dominus, também de Betim, trabalha com contêineres e insumo industrial do Rio Grande do Sul ao Rio de Janeiro; e Rodoban e Prosegur, ambas da capital, são especializadas em valores e malotes bancários. A Fátima, de 1962, tem matriz em Betim e se tornou uma das mais tradicionais em transporte de combustível e diversos insumos 
(emulsões para asfalto, gases industriais, cimento, cal, gás natural comprimido, minérios, enxofre, gesso, fertilizante, escória, brita, areia, carvão vegetal e coque), com filiais em Formiga (MG), Serra, Duque de Caxias, São José dos Campos, Goiânia e Vitória da Conquista. A Sete Lagos, de Sete Lagoas, transporta mudanças e encomendas.

É preciso mencionar que Minas Gerais é um grande ponto de passagem nacional nos sentidos norte-sul e leste-oeste e conta com a maior extensão rodoviária do país (cerca de 276 mil km), mas em condições não muito favoráveis por causa do gabarito geométrico utilizado no passado para vencer a sua topografia bastante irregular, com excesso de curvas e poucos túneis e viadutos. O Movimento Pró-Minas, criado por parlamentares do Estado, reivindica um conjunto de ações de incremento rodoviário, como a duplicação da BR-381 da capital a Governador Valadares; e a adequação e duplicação da BR-262 entre Nova Serrana (polo calçadista que conta com 10 fixos de ETCs de seis Estados) e Uberaba, entre outras.

De Belo Horizonte seguindo pela BR-262 na direção leste são 544 km até o litoral capixaba. Na Região Metropolitana da Grande Vitória/RMGV (lei complementar estadual $n^{\circ}$ 58/95), epicentro do eixo capixaba (DIAGRAMA 3),os portos de Vitória e Capuaba (Vila Velha) têm se destacado nos últimos anos por causa do elevado crescimento das importações de bens de consumo, veículos e maquinário especializado para a indústria petrolífera, gerando incremento de $15 \%$ a $20 \%$ para o TRC local, segundo dados do Sindicato das Empresas de Transportes de Cargas \& Logística no Estado do Espírito Santo (Transcares). Apenas em 2011 foram desembarcados cerca de 480 mil veículos. Ainda na RMGV, existem três Clias em Cariacica e um terminal de carregamento de combustível em Serra. As unidades do Sest/Senat ficam em Viana e Cariacica.

O Espírito Santo foi um dos Estados mais beneficiados pela chamada "guerra dos portos", provocada pelas reduções fiscais de ICMS sobre movimentações interestaduais de produtos importados. A medida eleva a arrecadação estadual e desenvolve os portos locais, pois não há cobrança fiscal no desembaraço da mercadoria, apenas nas barreiras fiscais rodoviárias de transposição interestadual. Alíquotas de 3\% a $5 \%$ estimularam o desembarque no porto de Vitória, enquanto as taxas cobradas em outros Estados variavam de $7 \%$ a $12 \%$. O importador gasta mais com logística, mas embolsa a diferença entre as tarifas. 
Na prática, a medida contribuiu para alavancar o TRC capixaba, mas houve conflitos nas divisas com Minas Gerais, que não concordava com esta política de incentivos. O resultado é que a rota pela BR-262, a principal ligação entre os Estados, tornou-se complicada, pois a Secretaria Estadual da Fazenda/MG colocou obstáculos à entrada de caminhões carregados com produtos importados via Espírito Santo. "Houve fiscalização mais rígida e maior tempo de espera”, afirmou Carlos Denis Rodrigues, gerente comercial da Belmok (informação verbal) ${ }^{9}$.

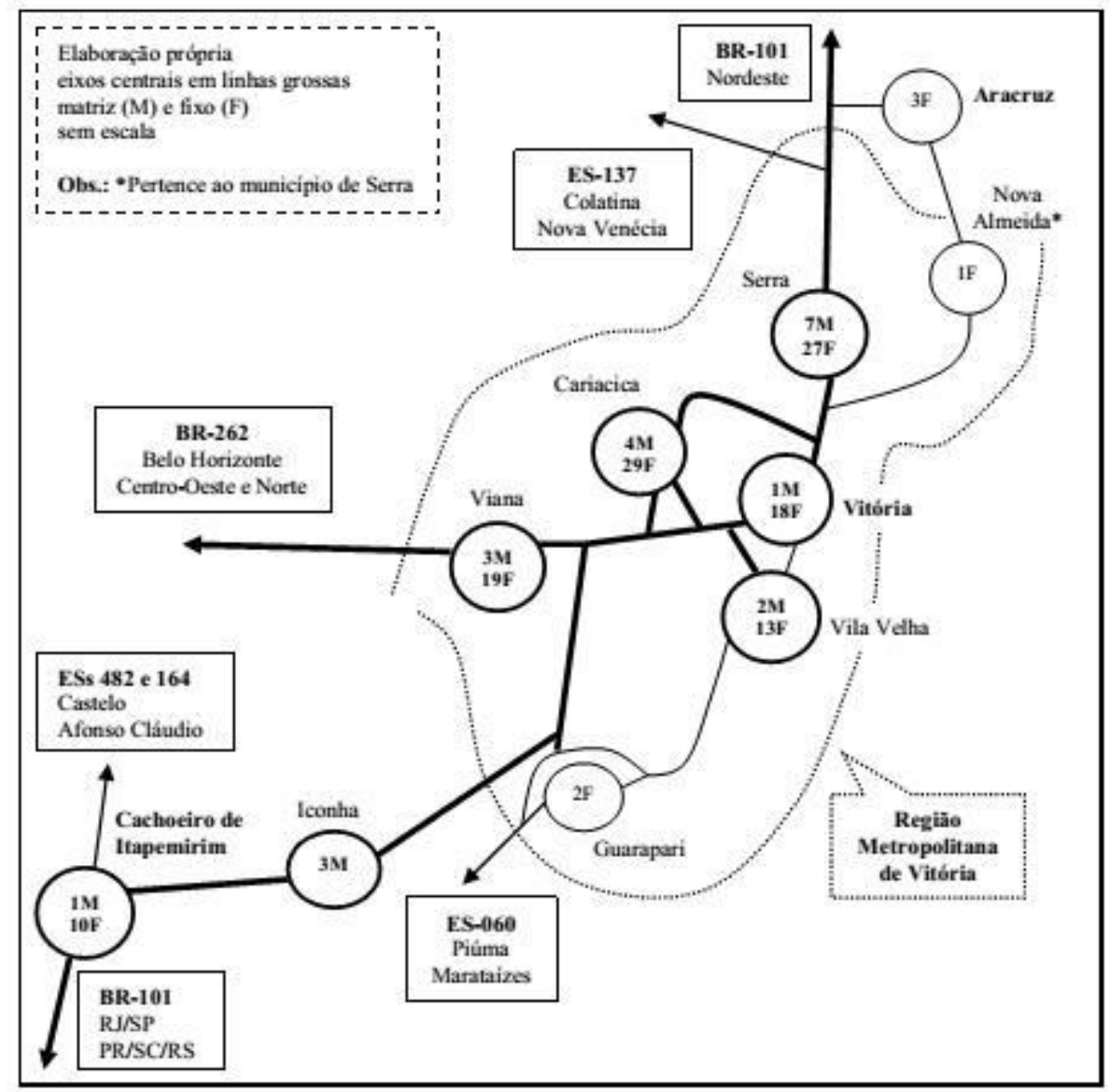

DIAGRAMA 3. Configuração territorial do eixo capixaba

Em abril de 2012, após forte movimentação de entidades industriais e operárias de todo o país, o Senado aprovou a resolução 72/10, que acabou com a prática a partir de janeiro de 2013 ao nivelar em 4\% a alíquota das operações interestaduais de ICMS para produtos importados. Produtos sem similar nacional, utilizados na produção da Zona Franca de Manaus e protegidos pela Lei de Informática e pelo Programa de Apoio 
ao Desenvolvimento Tecnológico da Indústria de Semicondutores (Padis) continuam gozando de benefícios.

O nexo territorial com Cachoeiro do Itapemirim, $140 \mathrm{~km}$ ao oeste pela BR-101 ou pela duplicada ES-060 (Rota do Sol), via Guarapari, reside no transporte das chamadas rochas ornamentais (mármores, granitos, ardósias e quartzitos) para exportação nos portos da RMGV. A "rota do mármore" tem em Cachoeiro o ponto de destino das rochas brutas, transportadas em caminhão pelas ESs 137 (extração em Nova Venécia e Colatina) e 166 (extração em Venda Nova do Imigrante). Após o processo de beneficiamento nas indústrias da cidade, a produção segue para o mercado interno e externo (70\% do total destinado à exportação), em fluxos T1/C que estão entre os mais densos do Estado. A cidade ainda possui uma unidade do Sest/Senat.

Outros fluxos intraestaduais de grande intensidade, completando os nexos territoriais do eixo nodal capixaba, são da planta siderúrgica da ArcelorMittal Tubarão, em Serra, ao seu terminal marítimo (transporte de bobinas, placas e chapas de aço para exportação), um percurso de $8 \mathrm{~km}$ pela ES-010; e em Aracruz, onde se registra o carregamento de toras de eucalipto para a fábrica de papel e celulose da Fibria (antiga Aracruz Celulose) - de sua reserva florestal própria e do Portocel, na Praia de Barra do Riacho, com coleta de madeira e celulose produzidos na unidade da Veracel na Bahia, mantida em joint venture com o grupo sueco-finlandês Stora-Enso.

As duas operações supracitadas estão sob a responsabilidade da Vix Logística, de Vitória, uma das maiores ETCs do Estado. Cheim, Tranfrisso, MRJS e Transuíça, todas de Serra, são especializadas em cargas especiais (a MRJS também trabalha com contêineres), sendo que a última mantêm fluxos T1 de São Paulo ao Ceará e Pará. Gold Star, de Viana, e Campo, de Cariacica, operam carga siderúrgica em sinergia com Minas Gerais.

Ainda em Cariacica, a Transilva transporte veículos, contêineres e carga especial. Colatinense, de Serra (de 1948), e Continental, de Vila Velha (de 1946), operam fluxos T1 com Estados vizinhos e fluxos T2 em todo o Espírito Santo, na carga geral. Nesse segmento, a Belmok, de Viana, é uma das maiores, com fluxos T1 entre Sudeste, Centro-Oeste e Nordeste. A Lippaus, de Cariacica, faz a rota com o Rio de Janeiro. A Itex é o setor de encomendas da Viação Itapemirim, de Cachoeiro, com 145 filiais por todo o Brasil otimizadas juntamente com o transporte de passageiros. 
Destaque ainda para MMA e CHC, de Serra, que transportam respectivamente carga geral e granéis sólidos; e PHT, de Viana, que opera carga siderúrgica para Volta Redonda e Contagem.

Iconha, na beira da BR-101, registra a maior concentração de caminhões do Estado. São da cidade a Jolivan (carga geral em 23 filiais de São Paulo a Ceará e Pará), Rodoplan (contêineres, insumo industrial e carga geral em todas as regiões do país) e Poloni (contêineres e carga geral para Santa Catarina e São Paulo). A Moreschi, de Vila Velha, é especializada no transporte de sensíveis e robótica (periféricos).

O fluxo-retorno para São Paulo é basicamente carga originada no Nordeste, fato que deprecia o valor do frete, segundo explicou Carlos Rodrigues, da Belmok. Citando valores, o frete-peso (carreta de 25 toneladas) Vitória-São Paulo é de $\mathrm{R} \$ 2.750$, contra $\mathrm{R} \$ 3,5$ mil no sentido inverso. É preciso ainda mencionar que a exportação de café da Serra Capixaba (que hoje segue por contêiner), a produção moveleira de Linhares e têxtil de Colatina constituem geração de carga regional para o TRC.

\section{Macaé: carga offshore no centro da cadeia logística da Petrobrás}

Mais de $80 \%$ da produção da Petrobrás é originada nos poços da Bacia de Campos, exploração petrolífera em águas profundas (offshore) que tem em Macaé, no litoral norte fluminense, o seu centro logístico. Do Porto de Imbetiba, de uso exclusivo da estatal petroleira, saem as embarcações de apoio às plataformas marítimas com todo o material necessário à atividade e sobrevivência dos trabalhadores que operam no alto-mar.

$\mathrm{Na}$ cidade estão instalados o polo offshore e o parque de tubos, onde se concentram as cerca de 4 mil empresas nacionais e estrangeiras (de 54 países) que fornecem equipamentos e serviços para a Petrobrás, como Halliburton, GE Oil\&Gas, Transocean, Sulzer, Selan Turbinas, Proenge, Orteng e Schlumberger, entre outras. A estadunidense GE, por exemplo, investiu US\$ 32 milhões na sua unidade de Macaé, focada na manutenção de equipamentos usados para extração e refino. A francesa Schlumberger, que vende, aluga e opera equipamentos como ferramentas de perfuração de poços, duplicou a sua estrutura na cidade com investimentos de US\$ 65 milhões, sua maior base operacional fora do país-sede. 
A atividade envolve serviços diferenciados para o TRC, uma espécie de operação dedicada de impacto territorial que envolve fluxos T1/B e T1/C - transporte de materiais e equipamentos importados pelos portos de Santos, Rio e Vitória - e T2/F, do polo offshore e parque de tubos ao Porto de Imbetiba, em distâncias médias de apenas $5 \mathrm{~km}$. Uma divisão territorial do trabalho baseada em serviços locais altamente especializados a cargo do circuito superior, pois requerem o uso de veículos equipados com guindastes (carretas munck) para içamento da carga. Nos fixos, é fundamental espaço disponível para armazenamento e o uso de empilhadeiras especiais.

A chamada carga offshore, de fretes altos e igualmente disputada pelo circuito superior, é composta por fluídos de perfuração e completação em integradores de cilindros (skids); estacas de sucção; granéis sólidos (cimento, baritina e bentonita) e líquidos (ácido para estimulação de poço); tubos de perfuração (drillpipes) e protetores correlatos (risers); brocas; árvores de natal (sistema de tubos de condução do óleo); mecanismo de prevenção de explosão (blowoutpreventer) e conjuntos de válvulas em bloco (manifolds), além de óleo diesel, materiais de uso rotineiro (cordas, cilindros de oxigênio e acetileno, gás freon, bobinas de cabo de aço e polipropileno etc) e água e alimentos para suprimento da tripulação em alto-mar. De modo geral, a carga é acondicionada em contêineres específicos, em tráfego constante e volumoso.

Quatro empresas transportadoras locais destacam-se, cujo nexo territorial se dá no fluxo de peças e equipamentos novos (importação e produção nacional) e usados para manutenção, transportados em contêiner ou caminhões-plataforma: Transmagno, com filiais em Guarulhos, Rio e Vila Velha; TNF, com filiais no Rio e Vila Velha; Rodomac, com filiais em São Paulo e Rio; e Predileto, com filiais em Guarulhos, Rio e Miracema (RJ). Transportadoras de outros Estados (SP/7, ES/4, MG/1 e PE/1) também instalaram filiais e algumas, como Vix, Superpesa e HM, operam no segmento offshore.

Para carga geral, registra-se o abastecimento de materiais de escritório e equipamentos de informática para a sede da Petrobrás e a sazonalidade do verão, quando uma quantidade expressiva de turistas tem como destino as praias da Região dos Lagos. Como destacou Leandro Espírito Santo, gerente da filial da Braspress na cidade (informação verbal) ${ }^{10}$, a unidade sob sua responsabilidade já expressa faturamento maior do que a filial de Campos dos Goytacazes, principal cidade de todo o Norte Fluminense e com população quase três vezes superior a de Macaé. 
Com as cidades vizinhas que completam o eixo nodal (DIAGRAMA 4), há sinergia ao longo de toda a RJ-106 até Arraial do Cabo, em percurso de $101 \mathrm{~km}$ que já se parece muito mais com o tráfego de uma avenida. Rio das Ostras, a $29 \mathrm{~km}$, está criando uma Zona Especial de Negócios (ZEN) para abrigar atividades mais ligadas à Petrobrás, além de acolher muitos funcionários que trabalham em Macaé.

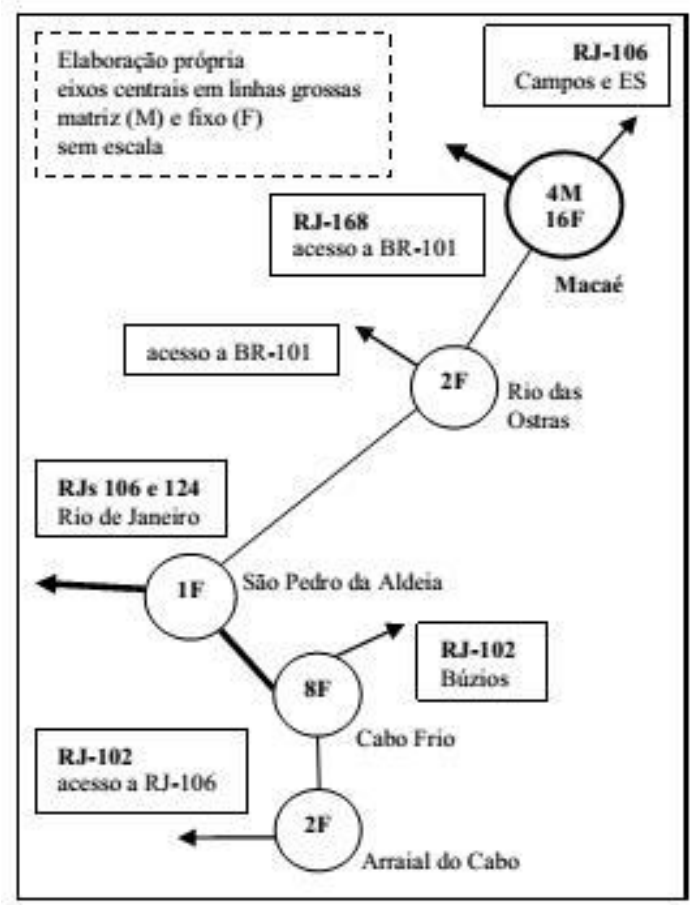

DIAGRAMA 4. Configuração territorial do eixo Macaé-Arraial do Cabo

Mais $58 \mathrm{~km}$ adiante, o aeroporto de Cabo Frio, explorado pela concessionária Costa do Sol desde 2001 (60\% da empresa foi adquirida pelo Grupo Libra no final de 2011), recebe cerca de 160 aviões cargueiros por ano com equipamentos destinados à atividade petrolífera de Macaé. Companhias como a brasileira Absa, a russa VolgaDnepr, a estadunidense Kalitta Air e a alemã Lufthansa Cargo, entre outras, operam voos semanais para a cidade fluminense. Mais $14 \mathrm{~km}$ ao sul está o Porto do Forno, em Arraial do Cabo, que também recebe carga de longo curso que segue por via rodoviária para Macaé, sobretudo protetores de tubos de perfuração (risers).

\section{Considerações finais}


A análise levou em conta um grande conjunto nodal definido por intensas interações espaciais. Além da relação com São Paulo, Minas Gerais, Espírito Santo e Rio de Janeiro têm como principais fluxos rodoviários interestaduais a ligação entre as suas capitais pelas BRs 040,101 e 262, como evidenciou a pesquisa. Os movimentos mais densos deste complexo em termos de TRC são notados no transporte de carga geral, carga siderúrgica e cargas especiais e de grande projeto, incluídas as cargas destinadas à logística de exploração offshore de petróleo, cujo epicentro fica em Macaé.

Segundo Romeu Scheibe Neto, coordenador-geral de operações rodoviárias do Departamento Nacional de Infraestrutura de Transpotes (DNIT) ${ }^{11}$, as BRs 153 e $251 \mathrm{em}$ Minas, e 116, 040 e 101, no Rio, estão entre as principais rotas do país para este segmento, além da 116 e 381 em São Paulo. Este fato evidencia o peso da produção de bens de capital e a proximidade com os portos de Vitória e Sepetiba, que recebem boa parte deste tipo de carga em caso de importação.

\section{Notas}

1 Entrevista concedida no Rio de Janeiro em 27.mai.2011.

2 Depoimento extraído do jornal O Estado de S. Paulo, Aliás/J8, de 10.jul.2011.

3Entrevista concedida em Resende (RJ) em 26.mar.2012.

4Colar metropolitano é um conjunto de municípios que reivindica a inclusão à região metropolitana adjacente.

5Criada em 2002 e sediada no Rio de Janeiro, a Anut congrega os principais embarcadores de grandes massas (granéis sólidos e líquidos) que têm na logística fator determinante para seus negócios. In Anuário NTC\&Logística 2008-09, p.49.

6Entrevista concedida no Terminal de Cargas Fernão Dias (São Paulo) em 30.abr.2012.

7 In FLEURY, Paulo Fernando. Evolução do desempenho das ferrovias brasileiras privatizadas: 1997 a 2010. Revista Tecnologística, ano XVIII, n 202, set.2012, p.9296.

8 Entrevista concedida em Belo Horizonte em 16.jun.2011.

9 Entrevista concedida em Viana (ES) em 29.mar.2012.

10 Entrevista concedida em Macaé em 04.abr.2012. 
11 In revista CNT Transporte Atual, ano XVIII, no 205, out.2012, p.29.

\section{Referências bibliográficas}

ARROYO, Mónica. Dinâmica territorial, circulação e cidades médias, in SPOSITO, Eliseu Savério; SPOSITO, Maria Encarnação Beltrão e SOBARZO, Oscar (orgs.). Cidades médias: produção do espaço urbano e regional. São Paulo: Expressão Popular, 2006, p.71-85.

La división territorial del trabajo: un proceso e una categoría para intepretar el mundo. Anais eletrônicos (cd-rom) da $4^{\text {a }}$ Conferência Internacional de Geografia Crítica, Ciudad de México, 2005, p.1-12.

BRAGA, Vanderlei. Logística e uso do território brasileiro: tipologia e topologia de nós logísticos e o projeto da Plataforma Multimodal de Goiás (PLMG). Tese de Doutorado, Universidade de Campinas (Unicamp/IGE), Campinas, 2013.

BRANDÃO, Antônio Carlos. Território e desenvolvimento: as múltiplas escalas entre o local e o global. $1^{\text {a }}$ reimp. Campinas: Unicamp, 2009.

CASTILLO, Ricardo Abid. Agricultura globalizada e logística nos cerrados brasileiros, in SILVEIRA, Márcio Rogério (org.). Circulação, transportes e logística. São Paulo: Outras Expressões, 2011, p.331-54.

CLOZIER, Réne. Géographie de lacirculation. Paris: Génin, 1963.

CORRÊA, Roberto Lobato. Estudos sobre a rede urbana. Rio de Janeiro: Bertrand Brasil, 2006. Interações espaciais, in CASTRO, Iná Elias de; GOMES, Paulo César da Costa e CORRÊA, Roberto Lobato (orgs.). Explorações geográficas: percursos no fim do século. Rio de Janeiro: Bertrand Brasil, 1997, p.279-318.

GIÚDICE, Fernando. Como gerir a variação sazonal da demanda, in Anuário NTC\&Logística 2011/2012, São Paulo, 2012, p.134-37.

Geo UERJ. Rio de Janeiro - Ano 16, no. 25, v.2, $2^{\circ}$ semestre de 2014, pp.366-396

ISSN: 1415-7543 E-ISSN: 1981-9021

http://www.e-publicacoes.uerj.br/index.php/geouerj 
HUERTAS, Daniel Monteiro. Território e circulação: transporte rodoviário de carga no Brasil. Tese de Doutorado, Departamento de Geografia, FFLCH/USP, São Paulo, 2013.

MARX, Karl. O capital: crítica da economia política - Livro Segundo: O processo de circulação do capital, volume III. 13.ed. Rio de Janeiro: Civilização Brasileira, 2011 [1893].

RAFFESTIN, Claude (1980). Por uma geografia do poder. São Paulo: Ática, 1993.

SANTOS, Milton (1979). O espaço dividido: os dois circuitos da economia urbana dos países subdesenvolvidos. $2^{\mathrm{a}}$ ed. $1^{\mathrm{a}}$ reimp. São Paulo: Edusp, 2008.

(1993). A urbanização brasileira. 5.ed. São Paulo: Edusp, 2005.

(1996). A natureza do espaço. Técnica e tempo. Razão e emoção. 4.ed.

São Paulo: Edusp, 2004.

(1979). Economia espacial: críticas e alternativas. 2.ed. São Paulo:

Edusp, 2003.

Metamorfoses do espaço habitado. São Paulo: Hucitec, 1988.

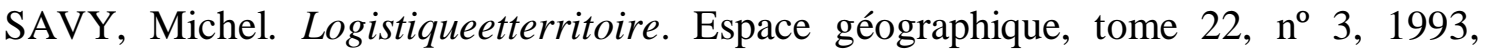
p.210-18.

SILVA JUNIOR, Roberto França. Geografia de redes e da logística no transporte rodoviário de cargas: fluxos e mobilidade geográfica do capital. Dissertação de Mestrado, Universidade Estadual Paulista (Unesp), Presidente Prudente, 2004.

THOMSON, J. M. Teoría económica del transporte. Madrid: Alianza Editorial, 1976. 
Artigo recebido para publicação em maio de 2014.

Artigo aceito para publicação em outubro de 2014.

Geo UERJ. Rio de Janeiro - Ano 16, no ${ }^{\circ}$ 25, v.2, $2^{\circ}$ semestre de 2014, pp.366-396

ISSN: 1415-7543 E-ISSN: 1981-9021

http://www.e-publicacoes.uerj.br/index.php/geouerj 